\title{
The effect of urbanization on population densities of forest passerine species in a Central European city
}

\author{
Grzegorz KoPIJ
}

Received: March 13, 2019 - Revised: April 15, 2019 -Accepted: May 16, 2019

Kopij, G. 2019. The effect of urbanization on population densities of forest passerine species in a Central European city. - Ornis Hungarica 27(1): 207-220. DOI: 10.2478/orhu-2019-0011

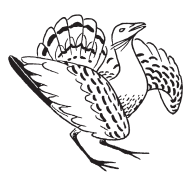

Abstract Typical, but less common, passerine forest species were selected for this study, such as Lullula arborea, Anthus trivialis, Troglodytes troglodytes, Prunella modularis, Turdus philomelos, Turdus viscivorus, Phylloscopus sibilatrix, Regulus regulus, Regulus ignicapillus, Muscicapa striata, Ficedula albicollis, Ficedula hypoleuca, Parus cristatus, Parus palustris, Parus ater, Certhia familiaris, Certhia brachydactyla, Oriolus oriolus, Garrulus glandarius, and Corvus corax. M. striata and T. philomelos were the most numerous among the 20 investigated species, the former one nested in a density of 6.7 pairs per 100 ha of wooded area, while the later one at 5.1 pairs per 100 ha. Density of most other species was below 3 pairs per 100 ha of wooded area. A. trivialis, $P$. cristatus and $P$. modularis were unexpectedly rare $(<1$ pair per 100 ha). Otherwise, relatively numerous were $T$. troglodytes $(1.8 \mathrm{p} . / 100 \mathrm{ha}), R$. regulus (1.8 p./100 ha) and $P$. palustris (1.4 p./100 ha). P. cristatus, L. arborea, and T. viscivorus were the rarest species investigated (below $0.1 \mathrm{p} . / 100 \mathrm{ha})$. Several bird species nested in wooded areas only in the outer zone of the city. This group included A. trivialis, R. regulus, P. ater, and C. corax. Population density of T. troglodytes, T. philomelos and O. oriolus were significantly higher in outer than in inner zone, while the reverse was true in the case of $M$. striata and F. hypoleuca.

Keywords: urban ornithology, urban ecology, urban forestry, population densities, Wroclaw

Összefoglalás A tanulmányhoz jellemző, de kevésbé gyakori erdei énekesmadár fajokat választottunk ki: Lullula arborea, Anthus trivialis, Troglodytes troglodytes, Prunella modularis, Turdus philomelos, Turdus viscivorus, Phylloscopus sibilatrix, Regulus regulus, Regulus ignicapillus, Muscicapa striata, Ficedula albicollis, Ficedula hypoleuca, Parus cristatus, Parus palustris, Parus ater, Certhia familiaris, Certhia brachydactyla, Oriolus oriolus, Garrulus glandarius és Corvus corax. A M. striata és a T. philomelos fajok voltak jelen legnagyobb számban a felsorolt 20 faj közül: elöbbi 6,7 pár/100 ha, míg utóbbi 5,1 pár/100 ha denzitással képviseltette magát. A legtöbb faj sürüsége a 3 pár/ 100 ha érték alatt maradt. Az A. trivialis, $P$. cristatus és a $P$. modularis meglepöen alacsony denzitással volt jelen (<1 pár/100 ha), a T. troglodytes (1,8 pár/100 ha), a $R$. regulus (1,8 pár/100 ha) és a $P$. palustris (1,4 pár/100 ha) viszonylag nagy számban fordult elő. A legritkább fajok a $P$. cristatus, $L$. arborea és a $T$. viscivorus voltak (kevesebb, mint 0,1 pár/100 ha). Néhány madárfaj kizárólag a városok körüli erdős területeken fészkelt. Ebbe a csoportba tartozik például az A. trivialis, $R$. regulus, P. ater és a C. corax. A T. troglodytes, T. philomelos és az $O$. oriolus populáció denzitása jelentősen nagyobb volt a városon kívüli, mint a városon belüli területeken, míg ennek fordítottja igaz például a M. striata és a $F$. hypoleuca esetében.

Kulcsszavak: urbanizáció, erdőborítottság, populáció denzitás, énekesmadarak, Wroclaw

Department of Vertebrate Ecology, Wroclaw University of Environmental \& Life Sciences Ul.Kozuchowska 5b,31-051 WroctawPoland,e-mail: gkopij@unam.na 


\section{Introduction}

The loss of natural areas for cities' development is regarded as ones of the main factors contributing to the decline of many wildlife species. This decline is further accelerated by environmental pollution, high level of human disturbance and predation by cats and dogs in a city environment. A city may, however, also create conducive environment for some species, as for example an abundance of food resources (processed food such as bread, milk products, meat, fruits, etc.), new nesting sites in man-mad structures (crevices and holes in buildings, artificial nest boxes, pipes, poles, etc.), specific microclimate with usually milder winters and springs, and lack of natural predators (Kalcey \& Rheinwald 2005, Sanesi et al. 2009). We can expect that some species may, therefore, benefit from city development and increase in number, but some other may not cope with the rapid environmental changes, may decrease in numbers and finally withdraw entirely from the city.

Among animals, birds appear to be sensitive to some of those changes, especially species which are strictly associated with forest as breeding and feeding habitats. This is because, forests become fragmented as a result of city expansion; older trees are often removed (lack of nesting sites for hole-nesting species), plant diversity is reduced and undergrowth (feeding place for some bird species) often impoverished (Kalcey \& Rheinwald 2005, Witt et al. 2005). There is also a high level of human disturbance in such habitats (sport, recreation, noise, management). We may, therefore, expect that typical forest species (those which do not breed in habitats other than forests) are negatively affected by urban development, and often disappear from cities, especially from their inner parts. In this study, I test the effect of the urbanization on selected forest species in one of the biggest Central European city.

\section{Study area}

The city of Wrocław (SW Poland), within its administrative boundaries, has a surface area of $293 \mathrm{~km}^{2}$ and the human population of 632996 (in 2010). It is situated in the large Odra Valley, where four other smaller rivers (Oława, Ślęża, Bystrzyca and Widawa) join the Odra river. There are large areas of grasslands and tree lines along these rivers.

In 2004, arable land comprised $44.8 \%$ of the total surface area, whereas $5.6 \%$ were covered with forests and wooded areas, $3.4 \%$ water, $9.8 \%$ roads, $18.7 \%$ built-up areas, $3.7 \%$ gardens, $6.1 \%$ recreational areas, and $1.3 \%$ wastelands (data from the city government). Marshlands and meadows comprised together $6.6 \%$.

There are 13 forests with a total surface area of 2,286 ha in Wrocław. Most of these forests are dominated by Tilio-Carpinetum stands, but forests situated in the western part (Mokrzański, Rędziński) are dominated by pines Pinus sylvestris. Among the biggest forests are Mokrzański (680 ha), Ratyński (295 ha) and Rędziński (218 ha).

In total, there are also 44 parks in Wroclaw, with a total surface of 781 ha. The biggest parks are: Szczytnicki (120 ha), Tysiąclecia (90 ha), Zachodni (75 ha), Grabiszyński (48 ha) and Wschodni (30 ha). Six other parks range in surface size from 10 to 29 ha, and the remaining are between 2 and 10 ha. Small afforested areas are scattered all over the city, especially in its SE part. 
Two zones were distinguished in the city: outer and inner (Figure 1). The zones differed in the proportion of densely built-up, open and afforested areas. In the inner zone of the city, most surface $(>50 \%)$ is covered with densely built-up areas, while in the outer zone - mostly $(>50 \%)$ with open (not built-up) and afforested areas. In the outer zone of the city afforested areas cover 2,380 ha, in the inner part -820 ha.

The climate of Wrocław is temperate, slightly warmer than the neighbouring areas. The mean annual temperature is $9.7^{\circ} \mathrm{C}$, with the monthly mean of the coldest month (January) $-0.5^{\circ} \mathrm{C}$, and the warmest month (July) $19.9^{\circ} \mathrm{C}$. The mean annual precipitation is $548 \mathrm{~mm}$. The mean annual humidity is $76 \%$. There are on average 158 days with rains per year, and 1,670 hours with sunny weather per year. The snow cover lasts on average 35 days per year (Smolnicki \& Szykasiuk 2002, Bryś \& Bryś 2010).

\section{Methods}

A simplified version of territory mapping method (Bibby et al. 2012) has been employed to plot on maps occupied territories of some less common species associated with forests, parks and other timbered areas as their breeding and feeding habitats. All such habitats within the administrative boundaries of Wrocław (Figure 1) were surveyed at least twice in breeding seasons. Different parts of the city were surveyed in different years, but each part was surveyed in one year only. Some of the parts were covered by Kopij $(2004,2005,2007$, 2008, 2010, 2014a, 2014b, 2014c, 2016). The whole area was covered within a period from 2002 to 2010. The timing and the effort of the survey were similar in these two zones (Figure 1).

Typical forest (those which do not occur in habitats other than forest), but not common ( $<10$ pairs per 100 ha wooded area) passerine species were selected for this study, such as Wood Lark Lullula arborea, Tree Pipit Anthus trivialis, Wren Troglodytes troglodytes, Dunnock Prunella modularis, Song Thrush Turdus philomelos, Mistle Thrush Turdus viscivorus, Wood Warbler Phylloscopus sibilatrix, Goldcrest Regulus

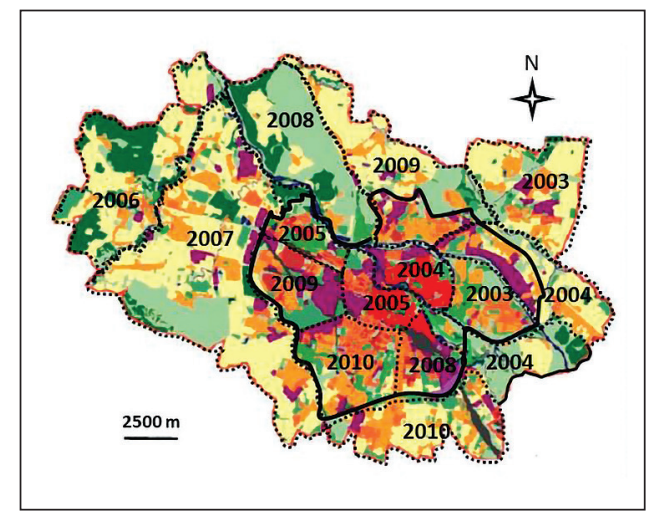

Figure 1. The study area (city of Wrocław). Black solid line - a border between the inner and outer zones of the city, black dashed line - borders of particular study plots (a year of survey is given). Black - railway, purple - industry areas, red - densely built-up areas, orange - loosely builtup areas, dark green - urbanized woods, light green - parks, seledin - grassy areas, yellow - arable grounds

1.ábra A vizsgált terület (Wrocław). A fekete folytonos vonal a belső és a külső területek közötti határt, a szaggatott vonal az időközönként vizsgált területeket jelöli a vizsgálati évek feltüntetésével. Fekete - vasútvonal, lila - iparterület, vörös - sűrűn beépített terület, narancs - kevésbé beépített terület, sötétzöld - városiasodott fás terület, világos zöld - park, seledin - füves terület, sárga mezőgazdasági terület 
regulus, Firecrest Regulus ignicapillus, Spotted Flycatcher Muscicapa striata, Collared Flycatcher Ficedula albicollis, Pied Flycacher Ficedula hypoleuca, Crested Tit Parus cristatus, Marsh Tit Parus palustris, Coal Tit Parus ater, Eurasian Treecreeper Certhia familiaris, Short-toed Treecreeper Certhia brachydactyla, Golden Oriole Oriolus oriolus, Jay Garrulus glandarius, and Raven Corvus corax.

Each seen or heard individual was plotted on the map 1:10 000. Special attention was paid to simultaneously singing males and birds performing other territorial and/or breeding behaviour. At least two records of such bird at the same site (in optimal habitat), made in at least three-week-interval, were assumed as representing an occupied territory, i.e. one breeding pair (Sutherland et al. 2004, Bibby et al. 2012).

Population density was expressed as the number of breeding pairs (= occupied territories) per 100 ha of wooded area. For this calculation, the total number of pairs recorded in all wooded areas in a given zone was taken into account. To test differences in the population density in the outer and inner zones, average population density (pairs per 100 ha of wooded areas) of each species was calculated for all wooded areas (forests, parks and all other timbered areas) in Wrocław. Based on these mean values, expected (proportional) numbers of breeding pairs was calculated separately for afforested areas in the outer and inner zones. These expected values were compared with actual numbers of recorded pairs in those two zones and the difference was tested using $x^{2}$-test.

Maps were generated to show the distribution of breeding pairs of all species under the study. The distribution is shown on the background of habitats in the city of Wroclaw, so as to elucidate habitat preferences.

\section{Results}

Population densities of 20 forest passerine species were determined and distribution of all breeding pairs recorded for each species are shown in Figure 2 (1-20). Most of these pairs nested in larger forests, less - in larger parks, and only few in other wooded places. In general, the larger the wooded area, the higher was the number of breeding forest passerine species.

The Spotted Flycatcher and Song Thrush were the most numerous among the 20 investigated species, the former one nested in a density of 6.7 pairs per 100 ha of wooded area, while the later one at 5.1 pairs per 100 ha. Density of most other species was below 3 pairs per 100 ha of wooded area. The Tree Pipit, Crested Tit and Dunnock were unexpectedly rare $(<1$ pair per $100 \mathrm{ha})$, while relatively numerous were the Wren (1.8 p./100 ha), Goldcrest (1.8 p./100 ha) and Marsh Tit (1.4 p./100 ha). The Crested Tit, Woodlark, and Mistle Thrush were the rarest species investigated (below 0.1 p./100 ha).

Among Muscicapidae, the Spotted Flycatcher was by far the most numerous species. Unexpectedly, the Collared Flycatcher was more numerous than the Pied Flycatcher, although the difference was not statistically significant $\left(x^{2}=2.17, \mathrm{p}>0.05\right)$. The population density of the Short-toed Treecreeper was significantly higher than that of the Eurasian Treecreeper $\left(x^{2}=16.93, \mathrm{p}<0.01\right)$. Among Turdus species, the Backbird Turdus merula was by far more numerous than the Song Thrush. The other member of this genus, the Mistle Thrush, was 
very rare, with only a single pair recorded. The proportion between Regulus regulus and $R$. ignicapillus was $0.83: 0.17(\mathrm{~N}=71$ pairs of both species); Certhia brachydactyla and $C$. $f a$ miliaris: $0.70: 0.30(\mathrm{~N}=109)$; Ficedula albicollis and F. hypoleuca: $0.57: 0.43(\mathrm{~N}=118)$.

Several bird species nested in wooded areas only in the outer zone of the city. The group included the Tree Pipit, Coal Tit, and Raven. Population density of the Wren, Song Thrush, and Golden Oriole were significantly higher in outer than in inner zone (Table 1), while the reverse was true in the case of the Spotted Flycatcher and Pied Flycatcher. No statistically significant differences in population densities of the Golden Oriole, Eurasian Treecreeper, Short-toed Treecreeper, Wood Warbler, Collared Flycatcher and Jay were recorded between outer and inner zones (Table 2). Very similar densities in outer and inner zones were recorded for species such as the Jay, Eurasian Treecreeper and Marsh Tit (Table 2).

Table 1. Density of selected forest bird species in the outer and inner parts of the city of Wrockaw. $\mathrm{N}$ - number of breeding pairs in all wooded areas in a given zone, D - density [pairs/100 ha of wooded area]

1. táblázat A vizsgált madárfajok területenkénti denzitása Wrocławban. N - költőpárok száma, D denzitás (pár/100 ha fás területegységre)

\begin{tabular}{|c|c|c|c|c|c|c|}
\hline \multirow[t]{2}{*}{ Species } & \multicolumn{2}{|c|}{$\begin{array}{c}\text { Outer zone } \\
{[2,380 \mathrm{ha}]}\end{array}$} & \multicolumn{2}{|c|}{$\begin{array}{c}\text { Inner zone } \\
\text { [820 ha] }\end{array}$} & \multicolumn{2}{|c|}{$\begin{array}{c}\text { Total } \\
{[3,200 \mathrm{ha}]}\end{array}$} \\
\hline & $\mathbf{N}$ & D & $\mathbf{N}$ & D & $\mathbf{N}$ & D \\
\hline Wood Lark & 2 & 0.08 & 0 & 0.00 & 2 & 0.06 \\
\hline Tree Pipit & 22 & 0.92 & 0 & 0.00 & 22 & 0.69 \\
\hline Wren & 55 & 2.31 & 3 & 0.37 & 58 & 1.81 \\
\hline Dunnock & 10 & 0.42 & 1 & 0.12 & 11 & 0.34 \\
\hline Song Thrush & 132 & 5.55 & 30 & 3.66 & 162 & 5.06 \\
\hline Mistle Thrush & 1 & 0.04 & 0 & 0.00 & 1 & 0.03 \\
\hline Wood Warbler & 71 & 2.98 & 31 & 3.78 & 102 & 3.19 \\
\hline Goldcrest & 38 & 1.59 & 21 & 2.57 & 59 & 1.84 \\
\hline Firecrest & 8 & 0.34 & 4 & 0.49 & 12 & 0.38 \\
\hline Spotted Flycatcher & 120 & 5.04 & 95 & 11.59 & 215 & 6.72 \\
\hline Collared Flycatcher & 43 & 1.81 & 24 & 2.93 & 67 & 2.09 \\
\hline Pied Flycatcher & 18 & 0.76 & 33 & 4.02 & 51 & 1.59 \\
\hline Marsh Tit & 37 & 1.55 & 9 & 1.10 & 46 & 1.44 \\
\hline Crested Tit & 3 & 0.13 & 0 & 0.00 & 3 & 0.09 \\
\hline Coal Tit & 45 & 1.89 & 0 & 0.00 & 45 & 1.41 \\
\hline Eurasian Treecreeper & 26 & 1.09 & 7 & 0.85 & 33 & 1.03 \\
\hline Short-toed Treecreeper & 51 & 2.14 & 25 & 3.05 & 76 & 2.38 \\
\hline Golden Oriole & 54 & 2.27 & 31 & 3.78 & 85 & 2.66 \\
\hline Jay & 47 & 1.97 & 16 & 1.95 & 63 & 1.97 \\
\hline Raven & 8 & 0.34 & 0 & 0.00 & 8 & 0.25 \\
\hline Total & 798 & 33.53 & 309 & 37.68 & 1,107 & 34.59 \\
\hline
\end{tabular}


Table 2. Statistical analysis ( $x^{2}$-test) of differences between population densities of some woodland bird species in inner and outer part of Wrocław city. Tested were only the species, for which expected value (between $\mathrm{N}$ and $\mathrm{E}$ ) was at least five. $\mathrm{N}$ - number of pairs recorded, $\mathrm{E}$ - expected number of pairs. Level of significance: ${ }^{*}:<0.05 ;{ }^{* *}:<0.01$

2. táblázat $\mathrm{A}$ vizsgált fajok populációdenzitás elemzésének eredményei. $\mathrm{N}$ - párok száma, $\mathrm{E}$ - a párok számának várt értékei. Szignifikancia szint ${ }^{*}:<0,05 ;{ }^{* *}:<0,01$

\begin{tabular}{|l|r|r|r|r|r|c|}
\hline \multicolumn{1}{|c|}{ Species } & \multicolumn{3}{|c|}{ Outer city } & \multicolumn{3}{c|}{ Inner city } \\
\hline & \multicolumn{1}{|c|}{ N } & \multicolumn{1}{c|}{ E } & \multicolumn{1}{c|}{$\boldsymbol{X}^{\mathbf{2}}$} & $\mathbf{N}$ & $\mathbf{E}$ & $\boldsymbol{x}^{\mathbf{2}}$ \\
\hline Wood Lark & 2 & 1.74 & & 0 & 0.00 & \\
\hline Tree Pipit & 22 & 19.18 & 0.83 & 0 & 0.00 & \\
\hline Wren & 55 & 47.95 & 2.07 & 3 & 1.88 & \\
\hline Dunnock & 10 & 8.72 & 0.38 & 1 & 0.63 & \\
\hline Song Thrush & 132 & 115.09 & $4.97^{*}$ & 30 & 18.84 & $13.21^{*}$ \\
\hline Mistle Thrush & 1 & 0.87 & & 0 & & \\
\hline Wood Warbler & 71 & 61.90 & 2.67 & 31 & 19.47 & $13.65^{* *}$ \\
\hline Goldcrest & 38 & 43.79 & 0.41 & 21 & 15.09 & 0.90 \\
\hline Firecrest & 8 & 6.98 & 0.30 & 4 & 2.51 & \\
\hline Spotted Flycatcher & 120 & 104.63 & $4.52^{*}$ & 95 & 59.67 & $41.83^{* *}$ \\
\hline Collared Flycatcher & 43 & 37.49 & 1.62 & 24 & 15.08 & $10.57^{* *}$ \\
\hline Pied Flycatcher & 18 & 15.69 & 0.68 & 33 & 20.73 & $14.53^{* *}$ \\
\hline Marsh Tit & 37 & 32.26 & 1.39 & 9 & 5.65 & 3.96 \\
\hline Crested Tit & 3 & 2.62 & & 0 & & \\
\hline Coal Tit & 45 & 39.23 & 1.69 & 0 & & \\
\hline Eurasian Treecreeper & 26 & 22.67 & 0.98 & 7 & 4.40 & \\
\hline Short-toed Treecreeper & 51 & 44.47 & 1.92 & 25 & 15.70 & $11.01^{* *}$ \\
\hline Golden Oriole & 54 & 47.08 & 2.03 & 31 & 19.47 & $13.65^{* *}$ \\
\hline Jay & 47 & 40.98 & 1.77 & 16 & 10.05 & $7.05^{*}$ \\
\hline Raven & 6.98 & 0.30 & 0 & & \\
\hline
\end{tabular}


Table 3. Population density of forest species in three selected large cities in Poland. $\mathrm{N}$ - number of breeding pairs, D - pairs/100 ha of wooded area

3. táblázat Erdei fajok populációdenzitás értékei három nagyobb lengyel városban. $\mathrm{N}$ - költőpárok száma, D - pár/100 ha fás területen

\begin{tabular}{|c|c|c|c|c|c|c|}
\hline City name & \multicolumn{2}{|c|}{ Warsaw } & \multicolumn{2}{|c|}{ Lodz } & \multicolumn{2}{|c|}{ Wroclaw } \\
\hline Total surface area & \multicolumn{2}{|c|}{494 km² $^{2}$} & \multicolumn{2}{|c|}{$293 \mathrm{~km}^{2}$} & \multicolumn{2}{|c|}{293 km $^{2}$} \\
\hline Wooded surface area & \multicolumn{2}{|c|}{$143.3 \mathrm{~km}^{2}$} & \multicolumn{2}{|c|}{$28.4 \mathrm{~km}^{2}$} & \multicolumn{2}{|c|}{$32 \mathrm{~km}^{2}$} \\
\hline Study period & \multicolumn{2}{|c|}{ 1986-1990 } & \multicolumn{2}{|c|}{ 2001-2008 } & \multicolumn{2}{|c|}{ 2002-2010 } \\
\hline Parameters & $\mathbf{N}$ & D & $\mathbf{N}$ & D & $\mathbf{N}$ & D \\
\hline Wood Lark & 0 & 0.0 & 30 & 1.1 & 2 & 0.1 \\
\hline Tree Pipit & 200 & 1.4 & 100 & 3.5 & 22 & 0.7 \\
\hline Wren & 500 & 3.5 & 70 & 2.5 & 58 & 1.8 \\
\hline Dunnock & 100 & 0.7 & 65 & 2.3 & 11 & 0.3 \\
\hline Song Thrush & 400 & 2.8 & 80 & 2.8 & 162 & 5.1 \\
\hline Mistle Thrush & 5 & 0.0 & 0 & 0.0 & 1 & 0.0 \\
\hline Wood Warbler & 600 & 4.2 & 200 & 7.0 & 102 & 3.2 \\
\hline Goldcrest & 10 & 0.1 & 30 & 1.1 & 59 & 1.8 \\
\hline Firecrest & 0 & 0.0 & 6 & 0.2 & 12 & 0.4 \\
\hline Spotted Flycatcher & 300 & 2.1 & 250 & 8.8 & 215 & 6.7 \\
\hline Collared Flycatcher & 5 & 0.0 & 2 & 0.1 & 67 & 2.1 \\
\hline Red-breasted Flycatcher & 10 & 0.1 & 16 & 0.6 & 0 & 0.0 \\
\hline Pied Flycatcher & 200 & 1.4 & 100 & 3.5 & 51 & 1.6 \\
\hline Marsh Tit & 40 & 0.3 & 80 & 2.8 & 46 & 1.4 \\
\hline Crested Tit & 40 & 0.3 & 250 & 8.8 & 3 & 0.1 \\
\hline Coal Tit & 30 & 0.2 & 64 & 2.3 & 45 & 1.4 \\
\hline Eurasian Treecreeper & 80 & 0.6 & 40 & 1.4 & 33 & 1.0 \\
\hline Short-toed Treecreeper & 80 & 0.6 & 146 & 5.1 & 76 & 2.4 \\
\hline Golden Oriole & 300 & 2.1 & 280 & 9.9 & 85 & 2.7 \\
\hline Jay & 250 & 1.7 & 260 & 9.2 & 63 & 2.0 \\
\hline Raven & 5 & 0.0 & 8 & 0.3 & 8 & 0.3 \\
\hline Total & 3,155 & 22.0 & 2,077 & 73.1 & 1,107 & 34.6 \\
\hline Sources & \multicolumn{2}{|c|}{ Luniak et al. 2001} & \multicolumn{2}{|c|}{ Janiszewski et al. 2009} & \multicolumn{2}{|c|}{ This study } \\
\hline
\end{tabular}




\section{Discussion}

In Wrocław, like in other Polish cities, species such as the Robin Erithacus rubecula, Wren, Song Thrush and Dunnock are relatively uncommon. For the contrast, in Western European cities, especially in the United Kingdom, they belong to the most common species in urbanized habitats (Mörtberg 2001, Otto et al. 2005). The Dunnock and Wren require dense undergrowth, which are often not available in urban parks. The Robin and Song Thrush forage on the ground among dead leaves and debris, and in Polish urban parks, these are often removed, so that the species are deprived of their main foraging grounds. The situation in urban parks in Western Europe is probably different in that sense.

The Collared Flycatcher is a newcomer to the city. During the years 1978-1987 it was not recorded at all in Wroclaw (Dyrcz et al. 1991), but in the years 2002-2010, it was already relatively numerous, even in the inner zone, where it occupied larger parks with old stands of common oaks, Quercus robur. Such situation is not known in any other Polish city. This would be, therefore, a first evidence of an urbanization of this species in Poland, and probably in Central Europe.

The first record of nesting Ravens were made in Wrocław in 1986 (Dyrcz et al. 1991), but it still occurs only on the periphery of the city, and nest only on trees. Also in other Polish cities, it was recorded only in the city peripheries and nesting on trees only (Luniak et al. 2001, Janiszewski et al. 2009, Zawadzka \& Zawadzki 2014). However, it is known to adopt electricity pylons and other man-made structures in farmlands in some parts of this country (Bednorz 2000, Zawadzka \& Zawadzki 2014). It is also well-known as having a wide spectrum of diet, and as being under a low predation pressure. Considering this wide ecological flexibility, weak synurbanization of Raven is a surprise. Other corvids such as the Hooded Crow Corvus cornix, Jackdaw Corvus monedula, Rook Corvus frugilegus and Magpie Pica pica have been well-adopted to urban environments for a long time. Probably high overall density of corvids in cities, especially that of the Hooded Crow Corvus cornix, is the reason for this weak Raven's synurbanization (Zawadzka \& Zawadzki 2014).

The Wood Warbler, a typical forest species, was relatively common in the city of Wrocław. Unexpectedly, it also nested in higher densities in inner than in outer zone. It prefers rather shady and humid places, with dense undergrowth, and this is often removed from most parks. It is virtually absent in West European cities (Mörtberg 2001, Witt et al. 2005).

The Golden Oriole nested in relatively high density in inner Wrocław, probably higher than in any other city in Poland and much higher than in West European cities (Witt et al. 2005). There is quite a dense net of rivers and canals, with numerous old oaks, poplars and other trees in the inner zone. This setting comprises optimal nesting habitat for the Oriole.

Except for the Great Tit Parus major and Blue Tit Parus caeruleus, all other species of the family Paridae were recorded as relatively rare in Wrocław, and the Willow Tit Parus montanus was not recorded at all. The Crested Tit and Coal Tit were found only in peripheral woods, and only the Marsh Tit was recorded in some urban parks in the inner zone. The Crested Tit, Coal Tit, Marsh Tit, Willow Tit are, however, area-sensitive species. Mörtberg (2001) has shown that they avoid urban forest patches which are smaller than 200-400 ha, and are virtually absent from those which are 10-30 ha in size. All forests are below 200 ha in the inner zone of Wrocław, whereas in the outer zone, there are only four such forests. 
In Wrockaw, both tree-creeper species occur often sympatrically at the same park or wood, and even in the same habitats. In such situation they appear to be territorial in relation to each other. The Short-toed Treecreeper is more common and more urbanized that the sibling species, but Wrocław is probably the only city in Poland where such proportions prevail. In all other cities, the proportion is probably reverse.

The Jay is relatively uncommon in Polish urban parks, probably as a result of competition with the Hooded Crow, which nest commonly in urban parks and in their close proximity. Urban parks are also usually devoid of dense young tree stands, which the species prefers as nesting habitat.

In some countries in Western Europe, population densities of most forest passerine species are completely different from those recorded in Wrocław and other big cities in Poland (Table 3). For example, in Sheffield, UK, a city comparable to Wrocław (surface area of $160 \mathrm{~km}^{2}$, and human population of 513 000), densities of the Wren, Robin, and Dunnock were higher than in Wrocław by the order of magnitude. Otherwise, species such as the European Nuthatch, Spotted Flycatcher had lower densities in Western European cities than in Wrocław. The Wood Warbler, Marsh Tit, Eurasian Treecreeper, Fieldfare, Golden Oriole, and Tree Sparrow are common in Wrocław, but were virtually absent in Sheffield (Fuller et al. 2009).

Only population size of the Jay and Coal Tit was comparable with that recorded in Wrocław, Warsaw or Łódź (Table 3). Similar large differences in population densities exist if Wrocław is compared to Berlin (Otto \& Witt 2002) or Hamburg (Mitschke \& Baumung 2001). There is a clear western gradient (an increase of population densities from cities in eastern towards cities in western Europe) for species such as the Dunnock, Wren, Robin, Blackbird, Song Thrush, Mistle Thrush, Chiffchaff, and Greenfinch, and an eastern gradient (an increase of population densities from cities in western towards cities in eastern Europe) for the Golden Oriole, House Sparrow (Witt et al. 2005) and probably for the Tree Sparrow, Spotted Flycatcher, Icterine Warbler, Marsh Warbler, Serine and Starling (Kopij 2014b, 2015). In the last two decades the Wood Pigeon, Blue Tit and Blackcap reached population densities typical for west European countries also in Wrocław and other towns and cities in SW Poland (own observ.).

Urban populations may buffer some bird species against regional population declines caused by agriculture intensification, increased predation or loss of suitable breeding habitats. It has been pointed out by many researchers (e.g. Gavareski 1976, Environment Canada 2007, Sanesi et al. 2009), that in inner zones of cities the forest patches, called parks, are often structurally less diverse than forests outside the city. As a result, most forest species have decreased population densities in cities than outside. This is due to the removal of undergrowth, ground cover and canopy layers, and old and dead trees (Gavereski 1976, Kopij 2015). However, in Wrocław this situation is not apparent. There are few forest species which have reduced numbers in inner forests, and few species which have increased, and still few others which remain the population density on similar level in forests of the inner and outer zone. In general, hole-nesting forest passerines are not affected. Some species foraging on the ground and shrub layers have indeed reduced densities (Song Thrush, Wren), but other species from this guild have remained similar or even increased densities (Wood Warbler, Marsh Tit). Thus, it is plausible, than factors such as nesting site availability, predation pressure and local microclimate may also play a role in the synurbanization of these wood passerine species in this part of Europe. 

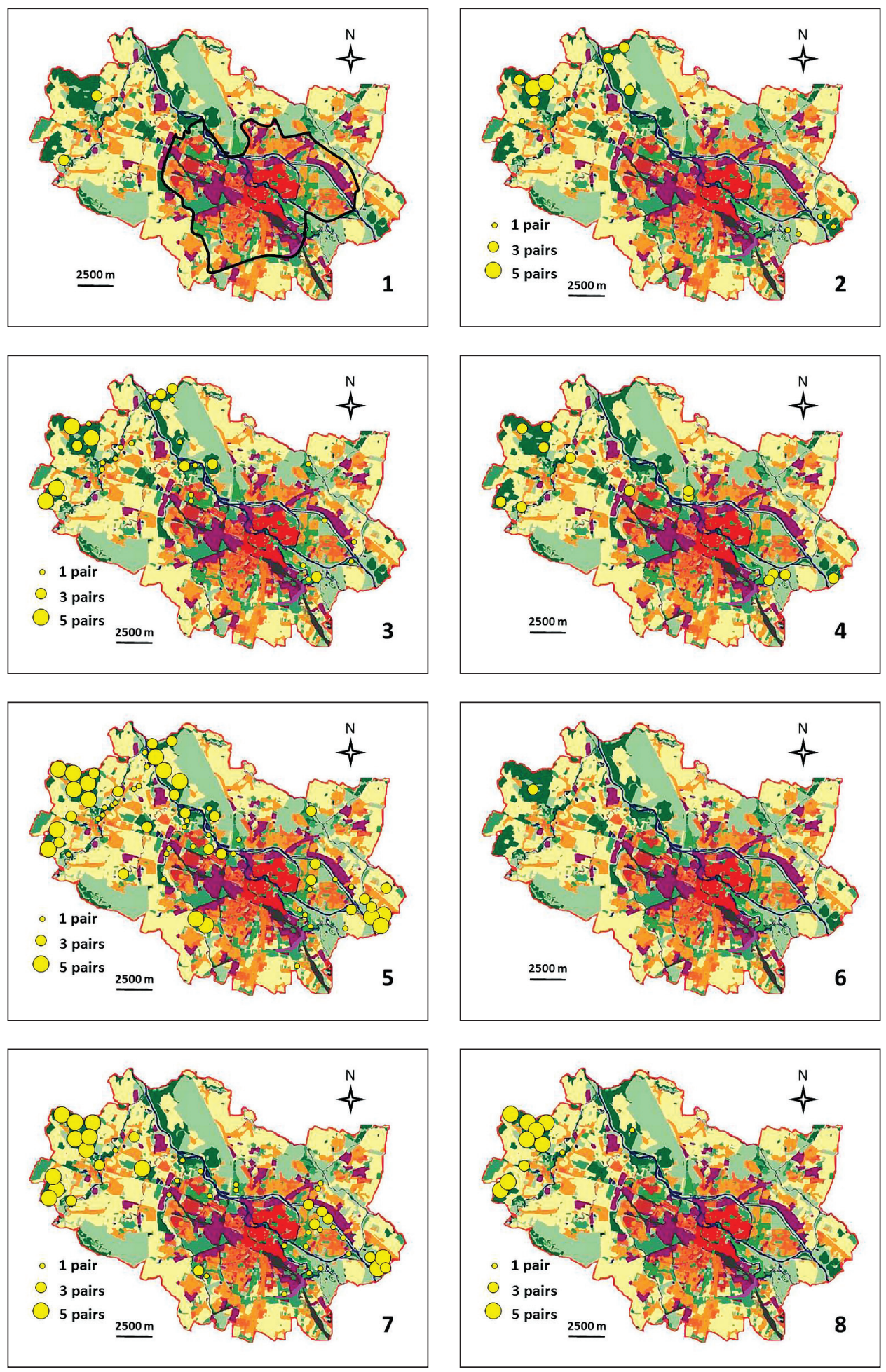

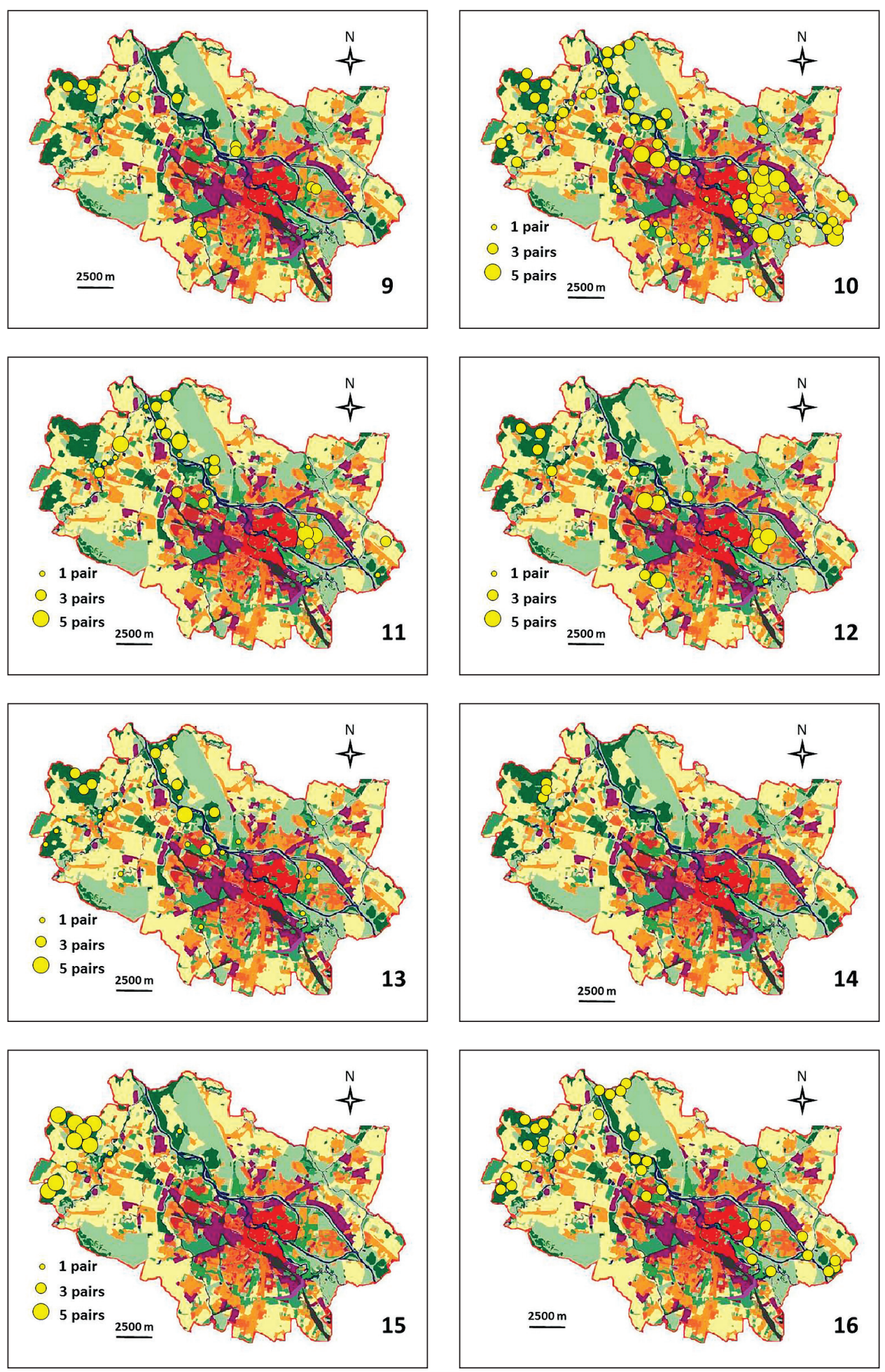

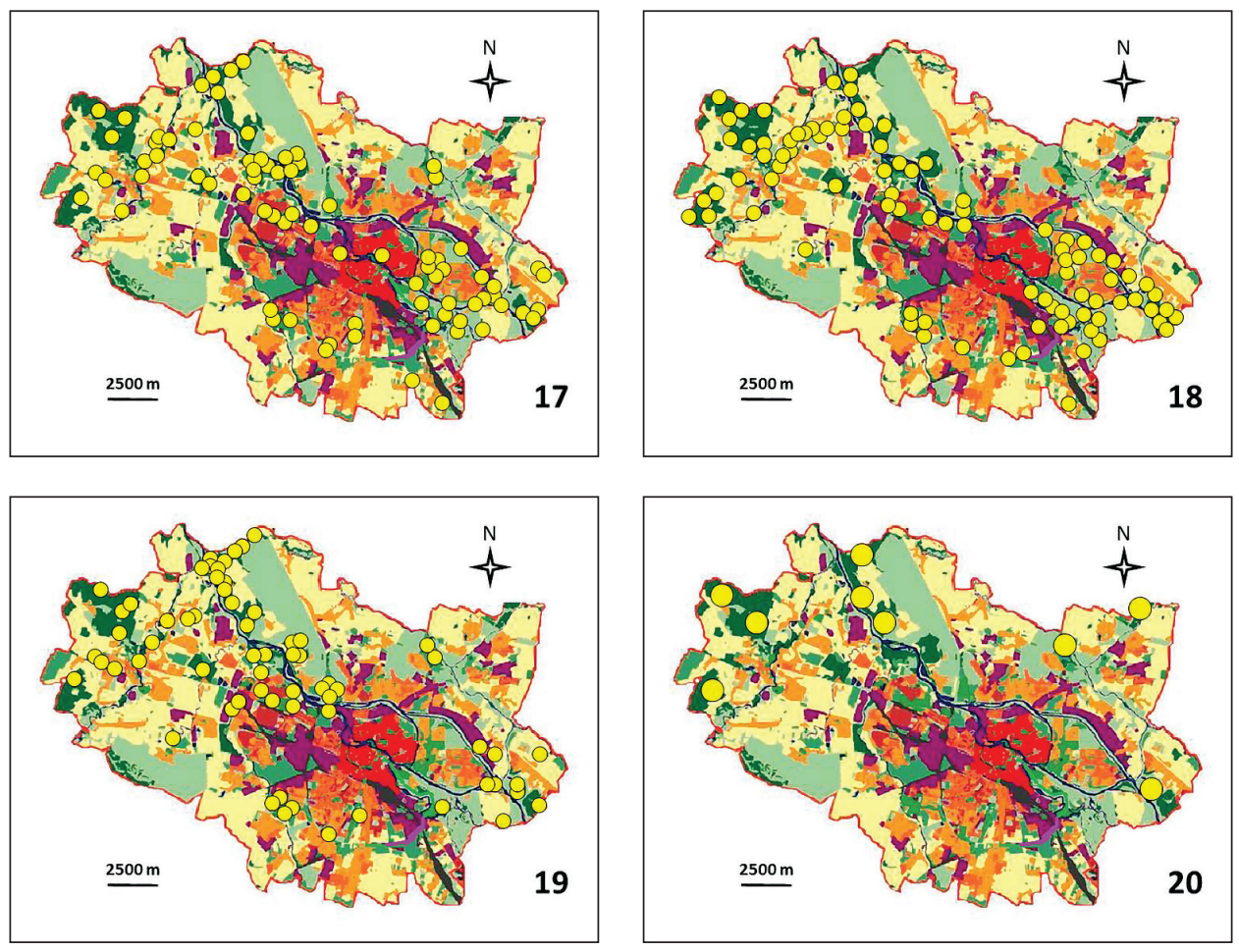

Figure 2. Distribution of studied species breeding pairs in the city of Wrocław during the years 2002-2010. The black continuous line indicate the border between inner and outer zone of the city. Black - railway, purple - industry areas, red - densely built-up areas, orange - loosely built-up areas, dark green - urbanized woods, light green - parks, seledin - grassy areas, yellow - arable grounds

1. Woodlark, 2. Tree pipit, 3. Wren, 4. Dunnock, 5. Song Thrush, 6. Mistletoe Thrush, 7. Wood Warbler, 8. Goldcrest, 9. Firecrest, 10. Spotted Flycatcher, 11. Collared Flycatcher, 12. Pied Flycatcher, 13. Marsh Tit, 14. Crested Tit, 15. Coal Tit, 16. Eurasian Treecreeper, 17. Short-toed Treecreeper, 18. Golden Oriole, 19. Jay, 20. Raven

2. ábra A vizsgált fajok elterjedése Wroclawban 2002-2010 között. A fekete folytonos vonal a belső és a külső területek közötti határt jelöli. Fekete - vasútvonal, lila - iparterület, vörös - sűrűn beépített terület, narancs - kevésbé beépített terület, sötétzöld - városiasodott fás terület, világos zöld - park, seledin - füves terület, sárga - mezőgazdasági terület 1. erdei pacsirta, 2. erdei pityer, 3. ökörszem, 4. erdei szürkebegy, 5. énekes rigó, 6. léprigó, 7. sisegő füzike, 8. sárgafejű királyka, 9. tüzesfejű királyka, 10. szürke légykapó, 11. örvös légykapó, 12. kormos légykapó, 13. barátcinege, 14. búbos cinege, 15. fenyvescinege, 16. hegyi fakusz, 17. rövidkarmú fakusz, 18. sárgarigó, 19. szajkó, 20. holló 


\section{References}

Bauer, H-G. \& Berthold, P. 1997. Die Brutvögel Mitteleuropas: Bestand und Gafährdung [Breeding birds of Central Europe: Population and Conservation]. - Aula-Verlag, Wiesbaden (in German)

Bednorz, J. 2000. Ravens Corvus corax Linnaeus, 1758, nesting on electricity pylons in the Wielkopolska region. - Acta Zoologica Cracoviensia 43: 177-184.

Bibby, C. J., Burgess, N. D. \& Hill, D. A. 2012. Bird census techniques. - Academic Press, London

Bryś, K. \& Bryś, T. 2010. Reconstruction of the 217-year (1791-2007) Wrocław air temperature and precipitation series. - Bulletin of Geography 3: 121-171. DOI: 10.2478/bgeo-2010-0007

Cramp, S. (ed.) 1979. The birds of western Palearctic. - Oxford University Press, Oxford

Dyrcz, A., Grabinski, W., Stawarczyk, T. \& Witkowski, J. 1991. Ptaki Śląska. Monografia faunistyczna [Birds of Silesia. A faunistic monograph]. - Uniwersytet Wrocławski, Wrocław (in Polish)

Environment Canada 2007. Area-sensitive forest birds in urban areas. - Environment Canada, Downsview (ON)

Fuller, R. A, Tratalos, J. \& Gaston, K. J. 2009. How many birds are there in a city of half a million people? - Diversity and Distribution 15: 328-337. DOI: 10.1111/j.1472-4642.2008.00537.x

Gavereski, C. A. 1976. Relation of park size and vegetation to urban bird populations in Seattle, Washington. Condor 78: 375-382.

Janiszewski, T., Wojciechowski, Z. \& Markowski, J. 2009. Atlas ptaków lęgowych Łodzi [Atlas of breeding birds of Lódź]. - Wydawnictwo Uniwersytetu Łódzkiego, Łódź (in Polish)

Kalcey, J. G. \& Rheinwald, G. (eds.) 2005. Birds in European cities. - Ginster Verlag, St. Catharinen

Kopij, G. 2004. Ptaki lęgowe Wielkiej Wyspy Szczytnickiego Zespołu Przyrodniczo-Krajobrazowego we Wrocławiu [Breeding birds of The Great Island of the Szczytnicki Complex of Protected Nature and Landscape in Wrocław]. - Zeszyty Naukowe Akademii Rolniczej we Wrocławiu Zootechnika 50(488): 187-204. (in Polish)

Kopij, G. 2005. Ptaki lęgowe zachodniej części Śródmieścia we Wrocławiu [Breeding birds of the western part of Śródmieście in Wrocław]. - Zeszyty Naukowe Akademii Rolniczej we Wrocławiu Zootechnika 53: 8799. (in Polish)

Kopij, G. 2006. Awifauna lęgowa Ziemi Grodkowskiej [Breeding avifauna of Grodków Land]. - Przegląd Przyrodniczy 17: 87-106. (in Polish)

Kopij, G. 2007. Ptaki Starego Miasta we Wrocławiu [Birds of Stare Miasto in Wrocław]. - Zeszyty Naukowe Akademii Rolniczej we Wrocławiu Zootechnika 55: 93-105. (in Polish)

Kopij, G. 2008. Awifauna legowa Obszaru Specjanje Ochrony Natura 2000 "Grady Odrzanskie" we Wroclawiu [Breeding avifauna of Special Protection Area Natura 2000 „Grądy Odrzańskie”]. - Parki Narodowe i Rezerwaty Przyrody 27: 95-114. (in Polish)

Kopij, G. 2010. Ptaki lęgowe północno-wschodniej części dzielnicy Fabrycznej we Wrocławiu. [Breeding birds of the north-eastern part of Fabryczna in Wrocław]. - Zeszyty Naukowe Akademii Rolniczej we Wrocławiu, Biologia i Hodowla Zwierząt 60: 77-96. (in Polish)

Kopij, G. 2012. Awifauna lęgowa Ziemi Nyskiej [Breeding avifauna of Nysa Land]. - Chrońmy Przyrodę Ojczystą 68(4): 259-287. (in Polish)

Kopij, G. 2014a Ptaki lęgowe klina zieleni w gradiencie urbanizacji na Krzykach we Wrocławiu [Breeding birds of a green area along urbanization gradient in Krzyki, Wrocław]. - In: Indykiewicz, P. \& Bohner, J. (eds.) Animal, Man and the City Interactions and Relationships. - Urban Fauna (Bydgoszcz) 6: 195-207. (in Polish)

Kopij, G. 2014b Breeding bird community of a large cemetery in a Central European city in 1969 and 40 years later. - Vogelwelt 135: 67-74.

Kopij, G. 2014c Population densities of birds breeding in urbanized habitats in the Grabiszyn district in the city of Wrocław. - Acta Musei Silesiae, Scientiae Naturales 63: 139-150. DOI: 10.2478/cszma-2014-0014

Kopij, G. 2015. The effect of the undergrowth on the breeding bird communities in urbanized afforested habitats. - Alauda 83: 23-31.

Kopij, G. 2016. Breeding bird assemblage in a mosaic of urbanized habitats in a Central European city. - Vestnik Zoologii 50(2): 163-172. DOI: 10.1515/vzoo-2016-0019

Lontkowski, J., Okulewicz, J. \& Drazny, T. 1988. Ptaki (Non-Passeriformes) pól irygacyjnych i terenów sąsiednich w północno-zachodniej części Wrocławia [Birds (Non-Passeriformes) polder fields and surrounding areas in the north-western part of Wrocław]. - Ptaki Śląska 6: 43-96. (in Polish) 
Luniak, M., Kozłowski, P., Nowicki, W. \& Plit, J. 2001. Ptaki Warszawy 1962-2000 [Birds of Warsaw $1962-$ 2000]. - Instytut Geografii i Przestrzennego Zagospodarowania Polskiej Akademii Nauk, Warszawa (in Polish)

Mitschke, A. \& Baumung, S. 2001., Brutvögel-Atlas Hamburg [Breeding bird Atlas of Hamburg]. - Hamburger Avifaunistische Beiträge 31. (in German)

Mörtberg, U. M. 2001. Resident bird species in urban forest remnants; landscape and habitat perspective. - Landscape Ecology 16: 193-203.

Otto, W. \& Witt, K. 2002. Verbreitung und Bestand Berliner Brutvögel [Breeding bird population and distribution in Berlin]. - Berliner Ornithologischer Bericht 12, Sonderheft (in German)

Otto, W., Mitschke, A. \& Luniak, M. 2005. Population densities of common breeding bird populations in Hamburg, Berlin and Warsaw. - Acta Ornithologica 40: 139-146.

Smolnicki, K. \& Szykasiuk, M. (eds.) 2002. Środowisko Wrocławia [Environment of Wrocław]. - Dolnośląska Fundacja Ekorozwoju, Wrocław (in Polish)

Sutherland, W. J., Newton, I. \& Green, R. E. 2004. Bird ecology and conservation. A handbook of techniques. Oxford University Press, Oxford

Szarski, K. W. 1955. Ptaki Wrocławia w latach 1946-1952 [Birds of Wrocław during the years 1946-1952]. - Acta Ornithologica 4: 1-50.

Witt, K., Mitschke, A. \& Luniak, M. 2005. A comparison of common breeding bird populations in Hamburg, Berlin and Warsaw. - Acta Ornithologica 40: 139-146. DOI: 10.3161/000164505775247737

Zawadzka, D. 2006. Kruk [Raven]. - Klub Przyrodnikow, Swiebodzin (in Polish)

Zawadzka, D. \& Zawadzki, G. 2014, Synanttropisation and synurbanization of the Raven Corvus corax in Poland. - International Studies on Sparrows 38: 11-16. DOI: 10.1515/isspar-2015-0025

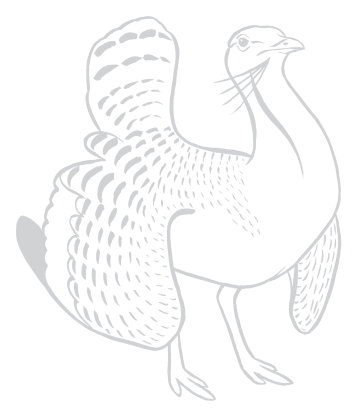

